Janos Kundrak, Antal Nagy, Miskolc, Hungary, Angelos P. Markopoulos, Nikolaos E. Karkalos, Athens, Greece

\title{
INVESTIGATION OF SURFACE ROUGHNESS ON FACE MILLED PARTS WITH ROUND INSERT IN PLANES PARALLEL TO THE FEED AT VARIOUS CUTTING SPEEDS
}

\begin{abstract}
In this paper, the roughness of the surface produced by symmetrical face milling is examined. During the research work, the effect of the use of a round milling insert on the surface topography was studied at different cutting speeds. $2 D$ and $3 D$ surface roughness measurements were carried out in three measurement planes parallel to the feed direction, one of them being the plane of symmetry and the other two planes being at the same distance from it, in both sides. From the analysis of results, it was found that surface roughness decreases significantly for cutting speed values over $100 \mathrm{~m} / \mathrm{min}$ and then its variation is minimal. Furthermore, higher values of surface roughness are observed in the symmetric plane than the other parallel planes and almost in every case, surface roughness was found to be larger on the entry side plane than the exit side plane.
\end{abstract}

Keywords: face milling; symmetrical milling; round insert; surface roughness.

\section{INTRODUCTION}

Surface quality is crucial for mechanical components, as it is one of the indicators of surface integrity and has a direct effect on product life and properties, such as corrosion resistance [1]. Although high surface quality at the last stages of the production of parts can be obtained by abrasive processes, such as grinding or polishing, it is important to achieve a sufficient surface quality from the early stages of manufacturing, e.g. by turning or milling. Especially in the case of milling, where the application of face milling technique is needed for the rendering of flat surfaces with enough dimensional accuracy, flatness and low surface roughness.

Regarding surface roughness during face milling, several works have been already reported in the relevant literature. Experimental studies have shown that surface roughness decreases at high cutting speed values [2-5], possibly due to more stable conditions and it was observed that machining performance is improved at intermediate and high cutting speeds $[4,5]$. Lower cutting speed values are also related to built-up edge creation and chip fracture, which leads to deterioration of surface quality, something that is not observed for higher cutting speeds $[2,4]$. Furthermore, an increase of feed rate, axial and radial depth of cut also lead to deterioration of surface quality $[2,4,5]$.

Apart from the purely experimental investigations, various researchers have proposed predictive models for surface roughness during face milling. Felhő et al. [6] presented a detailed methodology for the prediction of surface roughness in face milling with different types of cutting inserts, such as polygonal, round 
and triangular. In their model, they modeled in detail the insert geometrical features and taking into account technological parameters of the process they were able to calculate the insert trajectory relative to the workpiece and finally, the topography of the milled surface. By comparing the results with experimental ones, they achieved sufficient accuracy regarding the prediction of $R_{a}$ and $R_{t}$. Baek et al. [7] developed a theoretical model for surface roughness during face milling including runout errors in order to optimize the feedrate. The simulated surface profile for a number of revolutions of the milling head was employed in an optimization process for the selection of optimum feed rate. They found that the correlation between surface roughness and feed rate was highly non-linear and confirmed the accuracy of their model in comparison with experimental results. Muñoz-Escalona and Maropoulos [8] proposed a methodology for surface roughness prediction in face milling, focusing mainly on insert geometry. Comparison with experimental results proved the adequacy of the model, not only for the prediction of 2D roughness indicators but also for the $2 \mathrm{D}$ roughness profile. Zhenyu et al. [9] proposed a surface roughness predictive model including both static and dynamic characteristics of the process. More specifically, their model consisted of two parts: the static part took into account geometrical characteristics of the cutting inserts and runout, whereas the dynamic part took into consideration the displacements induced by forced and self-excited vibration of the cutting insert. The final model was superior to the models neglecting the dynamic behavior of the cutting insert, as the predicted 2D roughness profile was closer to the experimental 2D roughness profile. Wang et al. [10] developed a mathematical model to predict surface roughness in face milling with triangular inserts with round corner. This model included three different equations for different feed rate values and after it was compared to the experimental results, it was found that it was more accurate than other existing mathematical models. Pimenov et al. [11] compared various artificial intelligence methods, such as random forest, multilayer perceptron, regression trees and radial-basis functions for the prediction of surface roughness by monitoring tool wear. After the analysis of their results, they pointed out that the random forest and regression tree methods were not only more accurate than the others, but were able to provide important information about the relations between input and output variable as well as their critical values, which should be checked in order to prevent undesirable results.

Although most researchers focus on the correlation of process parameters and surface roughness, only a few have conducted studies on the effect of milling strategy such as symmetric or asymmetric milling on the surface quality during face milling. Comparing symmetric and asymmetric machining strategy, Bagci and Aykut [12] deduced that roughness was lower during symmetric face milling. Furthermore, Cui and Zhao [13] compared up, down and symmetric milling and 
showed that up milling was the most preferable milling strategy up to a certain cutting speed value after which symmetric milling was more preferable. Moreover, Varga and Kundrák [14] found that surface roughness in symmetric milling decreases as the distance from the middle plane increases and the decrease is larger for larger feed rate values.

In the present work, an experimental study is conducted to determine the effect of cutting speed on surface roughness during face milling. In contrast to the majority of previous works, 2D and 3D surface roughness parameters are calculated not only in a specific position or plane but in three different parallel planes on the feed direction in order to analyze the variation of surface roughness with the distance from the symmetric plane.

\section{EXPERIMENTAL CONDITIONS}

In the present paper, experimental tests are carried out regarding face milling of steel workpieces, with a single cutting insert at various cutting speeds. The milling experiments were performed in a Perfect Jet MCV-M8 CNC vertical machining center. During machining, a face milling head was used with only one round coated carbide insert of RCKT1204M0-PM type mounted on it. The milling head had a nominal diameter $\left(D_{t}\right)$ of $68 \mathrm{~mm}$ and the insert had a rake angle $\left(\gamma_{\mathrm{o}}\right)$ of $0^{\circ}$ and relief angle $\left(\alpha_{\mathrm{o}}\right)$ of $7^{\circ}$.

Table 1 - Cutting data for the experiments

\begin{tabular}{|c|c|c|c|c|}
\hline No. & $\begin{array}{c}\mathbf{a e} \\
{[\mathrm{mm}]}\end{array}$ & $\begin{array}{c}\text { ap } \\
{[\mathrm{mm}]}\end{array}$ & $\begin{array}{c}\mathbf{f z} \\
{[\mathrm{mm} / \mathrm{rev}]}\end{array}$ & $\begin{array}{c}\mathbf{v c} \\
{[\mathrm{m} / \mathrm{min}]}\end{array}$ \\
\hline 1 & \multirow{5}{*}{58} & \multirow{5}{*}{0.8} & \multirow{5}{*}{0.4} & 100 \\
\hline 2 & & & & 200 \\
\hline 3 & & & & 300 \\
\hline 4 & & & & 400 \\
\hline 5 & & & & 500 \\
\hline
\end{tabular}

The workpieces used for the experiments are made of a normalized C45, 1.0503 grade carbon steel. The material has a hardness of HB207 and a tensile strength of $\mathrm{Rm}=580 \mathrm{MPa}$ [15]. The cutting length is $50 \mathrm{~mm}$ and the width of cut is $58 \mathrm{~mm}$ on the milled surfaces of the samples. During the experimental work the cutting speed $\mathrm{v}_{\mathrm{c}}$ was varied in the range of 100 to $500 \mathrm{~m} / \mathrm{min}$, whereas the other process parameters, such as the depth of cut and the feed per tooth had constant values, which are $a_{p}=0.8 \mathrm{~mm}$ and $\mathrm{f}_{\mathrm{z}}=0.4 \mathrm{~mm}$, respectively. These details can be 
found in Table 1. The surfaces were produced with symmetrical setting of face milling under dry machining conditions.

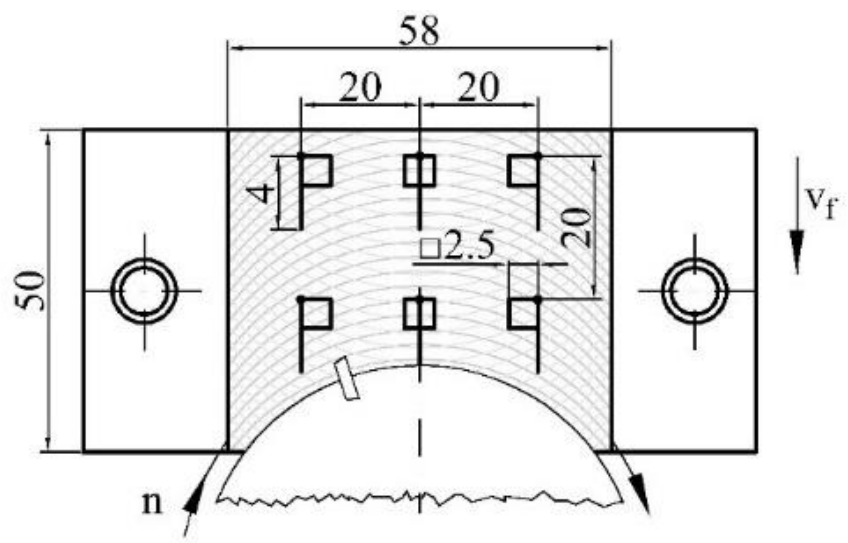

Figure 1 - Positions of the surface roughness measurements on the workpiece surface

2D and 3D roughness measurements were performed on an AltiSurf 520 three-dimensional surface roughness measuring device and a confocal chromatic sensor was used for the measurements. After the measurements, evaluation of the results and calculation of $2 \mathrm{D}$ and $3 \mathrm{D}$ roughness parameters was conducted using AltiMap Premium software. During the measurements, the roughness was examined in three planes parallel to the direction of the feed; one on the middle plane and two planes at equal distance $(20 \mathrm{~mm})$ from that and towards different sides; these planes will be denoted afterwards as entry and exit side plane, respectively. The measurements were carried out twice in each plane with a $20 \mathrm{~mm}$ separation, as specified in Figure 1. The lengths of 2D measurements were $4 \mathrm{~mm}$, in accordance with ISO 4288:1998 and areas of $2.5 \times 2.5 \mathrm{~mm}$ for $3 \mathrm{D}$ evaluations were recorded, which are illustrated with lines and squares in Figure 1, among the workpiece movement and milling head rotation directions.

\section{RESULTS OF EXPERIMENTS}

After the experimental work was carried out, all machined samples were measured thrice, the results were then processed by the aforementioned software and finally surface roughness parameters were computed. The average results of the measurements, regarding 2D and 3D surface roughness parameters (namely $R_{a}, R_{z}, S_{a}$ and $S_{z}$ ) are summarized in Table 2 and 3 for all cutting speeds and for the three parallel planes. Furthermore, the roughness 
profile curves for $\mathrm{v}_{\mathrm{c}}=100,300$ and $500 \mathrm{~m} / \mathrm{min}$ are presented in Figure 2, and the recorded topography of machined surface for the same conditions are shown in Figure 3.

Table 2-2D Surface roughness values for each case

\begin{tabular}{|l|l|l|l|l|l|l|}
\hline \multirow{2}{*}{$\begin{array}{l}\mathbf{v}_{\mathbf{c}} \\
{[\mathrm{m} / \mathrm{min}]}\end{array}$} & \multicolumn{2}{|c|}{$\mathbf{R}_{\mathbf{a}}[\mu \mathrm{m}]$} & \multicolumn{3}{c|}{$\mathbf{R}_{\mathbf{z}}[\mu \mathrm{m}]$} \\
\cline { 2 - 7 } & Entry & Symm & Exit & Entry & Symm & Exit \\
\hline $\mathbf{1 0 0}$ & 3.789 & 3.367 & 2.509 & 19.596 & 16.181 & 14.026 \\
\hline $\mathbf{2 0 0}$ & 0.807 & 0.949 & 0.750 & 4.626 & 4.731 & 4.467 \\
\hline $\mathbf{3 0 0}$ & 0.805 & 0.942 & 0.784 & 4.981 & 4.692 & 4.503 \\
\hline $\mathbf{4 0 0}$ & 0.800 & 0.940 & 0.768 & 4.477 & 4.505 & 4.294 \\
\hline $\mathbf{5 0 0}$ & 0.758 & 1.030 & 0.761 & 4.691 & 5.306 & 4.320 \\
\hline
\end{tabular}

Table 3 - 3D Surface roughness values for each case

\begin{tabular}{|l|l|l|l|l|l|l|}
\hline \multirow{2}{*}{$\begin{array}{l}\mathbf{v} \\
{[\mathrm{m} / \mathrm{min}]}\end{array}$} & \multicolumn{3}{|c|}{$\mathbf{S}_{\mathbf{a}}[\mu \mathrm{m}]$} & \multicolumn{3}{c|}{$\mathbf{S}_{\boldsymbol{z}}[\mu \mathrm{m}]$} \\
\cline { 2 - 7 } & Entry & Symm & Exit & Entry & Symm & Exit \\
\hline $\mathbf{1 0 0}$ & 4.127 & 3.781 & 3.741 & 26.734 & 29.170 & 25.626 \\
\hline $\mathbf{2 0 0}$ & 0.885 & 0.999 & 0.828 & 4.523 & 4.907 & 4.431 \\
\hline $\mathbf{3 0 0}$ & 0.876 & 1.027 & 0.850 & 4.679 & 4.770 & 4.221 \\
\hline $\mathbf{4 0 0}$ & 0.854 & 1.011 & 0.855 & 4.358 & 4.505 & 4.148 \\
\hline $\mathbf{5 0 0}$ & 0.758 & 1.030 & 0.761 & 4.691 & 5.306 & 4.320 \\
\hline
\end{tabular}

\section{DISCUSSIONS}

In case of milling, the topography of the surface is formed with a rotating tool, so it will be different compared to e.g. turning, due to other relative movements of the tool and the workpiece. If the axis of the face milling tool moves on the symmetry plane of the machined surface, the cutting insert is performing up-milling in the first half of the chip removal process, and then the milling process is changed to down-milling for the second half. For that reason, the measurements were carried out in the middle plane and in two parallel planes on two opposite sides. Generally, it can be stated that the roughness values obtained from the surface created by the round shaped insert first decrease suddenly and then remain practically unchanged with an increase of the cutting speed. This can be further proved by the $2 \mathrm{D}$ surface roughness profiles depicted in Figure 2, as the variety of roughness profiles is minimal between cases at $300 \mathrm{~m} / \mathrm{min}$ and $500 \mathrm{~m} / \mathrm{min}$ cutting speeds in comparison to the variation of roughness profiles between cases at $100 \mathrm{~m} / \mathrm{min}$ and $300 \mathrm{~m} / \mathrm{min}$. 


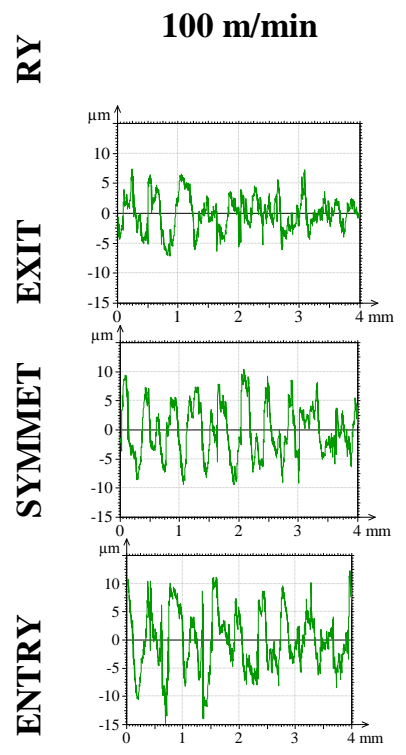

\section{$300 \mathrm{~m} / \mathrm{min}$}
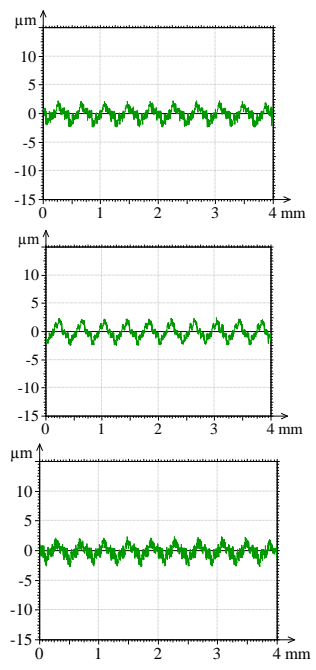

$500 \mathrm{~m} / \mathrm{min}$
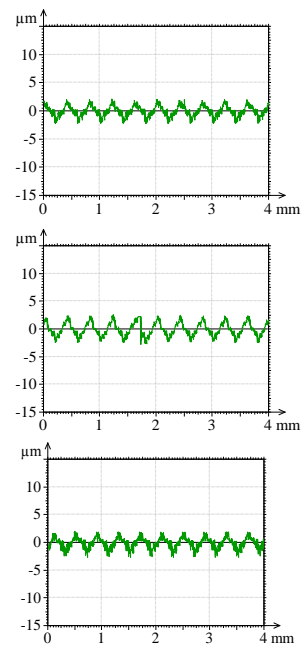

Figure $2-2 \mathrm{D}$ roughness profile curves of milled surfaces

Comparing the roughness values of surfaces machined with the smallest and largest cutting speeds, it can be concluded that increasing the cutting speed in the studied range reduces the surface roughness values. In the symmetry plane, the $R_{a}$ decreases by $69.4 \%$, the $R_{z}$ by $67.2 \%$, the $S_{a}$ by $71.8 \%$, the $S_{z}$ by $82.9 \%$. On the exit side, the rate of decrease is almost the same as that observed in the middle plane. On the entry side, however, there is a greater change; the percentage change is $80 \%$ for $R_{a}, 76.1 \%$ for $R_{z}, 79.9 \%$ for $S_{a}$ and $83.9 \%$ for $\mathrm{S}_{\mathrm{z}}$. This greater change is due to the fact that the highest measured values are observed in the entry side in almost every case at the lowest speed of $100 \mathrm{~m} / \mathrm{min}$, while in the case of cutting speed of $200 \mathrm{~m} / \mathrm{min}$ and above, the maximum values of the observed roughness occurs for most cases in the symmetric plane, as it was observed also in the relevant literature [14].

Since the variation of roughness is not monotonic with the increase of cutting speed, it is advisable to conduct the analysis separately for the speed of $100 \mathrm{~m} / \mathrm{min}$ and speeds in the range of 200 to $500 \mathrm{~m} / \mathrm{min}$. The significant difference in surface quality between cases at $100 \mathrm{~m} / \mathrm{min}$ and the other cases is further stressed by observing the $3 \mathrm{D}$ surface roughness profiles of Figure 3. In the case of cutting speeds over $100 \mathrm{~m} / \mathrm{min}$, more straight and smooth micro-grooves are observed on the milled surfaces, whereas more irregular ones occur in the case of $100 \mathrm{~m} / \mathrm{min}$. 
So, although the general shape and direction of the grooves on the same measurement plane are similar for the various setups (circular patterns for the entry and exit sides and an almost straight, vertical line for the symmetric plane), the increase of cutting speed leads to more stable conditions for milling, and consequently to better surface quality.

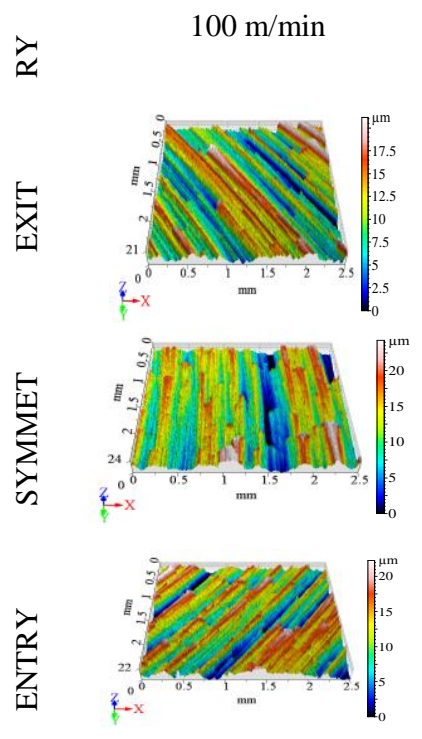

$300 \mathrm{~m} / \mathrm{min}$
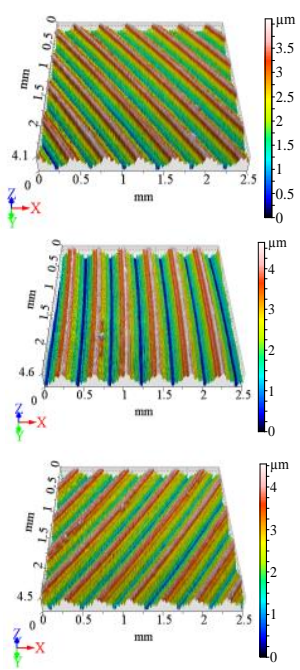

$500 \mathrm{~m} / \mathrm{min}$
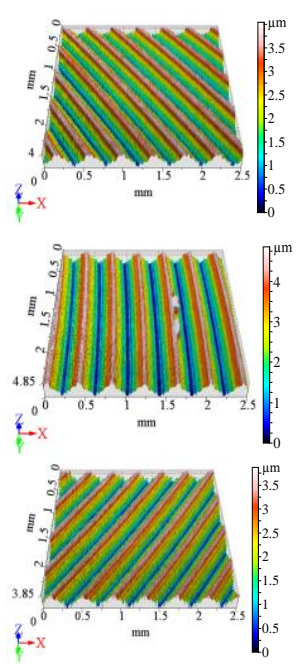

Figure 3 - Surface topography images of milled surfaces

Compared to the actual roughness values in the middle plane, the deviations of the measured values on the entry and exit sides are shown in Figures 4 and 5. In these figures, it can be seen that at a speed of $100 \mathrm{~m} / \mathrm{min}$, higher roughness was measured on the entry side, except for $S_{z}$, and apart from the small differences, surface roughness is smaller in the entry and exit sides for the other cases. Moreover, the deviations at 200, 300, $400 \mathrm{~m} / \mathrm{min}$ are relatively smaller than those at the lowest and the largest cutting speeds. In most cases, the charts show the highest ratios at $500 \mathrm{~m} / \mathrm{min}$, so it means that the greatest inhomogeneity of the surface is generated with the highest examined cutting speed.

The roughness values on the entry and exit sides show observable differences. On the plane of the entry side, the roughness values of both $2 \mathrm{D}$ and $3 \mathrm{D}$ parameters for all cutting speeds are nearly the same or greater than the 
respective values of roughness values on the exit side plane. Moreover, by increasing the cutting speed, the respective values of roughness on the entry and exit side planes are getting closer together. The largest differences between surface roughness values at the entry and exit side planes are always obtained at a cutting speed value of $100 \mathrm{~m} / \mathrm{min}$, where the ratio of surface roughness parameters is $151 \%$ for $R_{a}, 110.3 \%$ for $R_{z}, 139.7 \% \%$ for $S_{a}$ and $104.3 \%$ for $S_{z}$. For larger cutting speeds, the ratio of surface roughness values between entry and exit side is significantly lower. The minimal differences can be observed at $500 \mathrm{~m} / \mathrm{min}$ for almost every parameter.

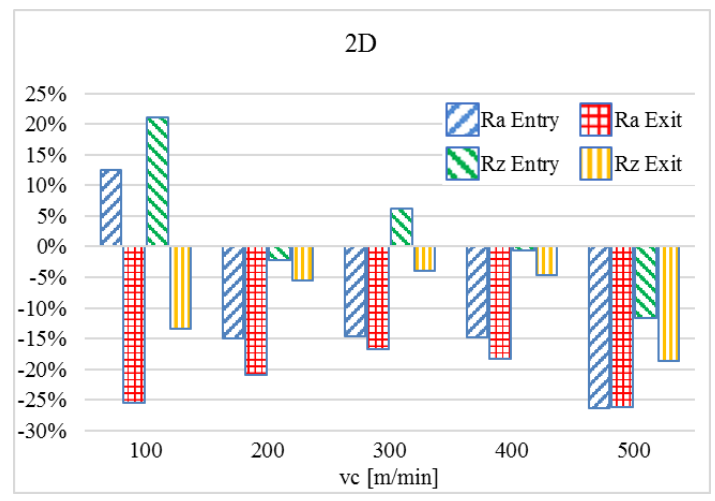

Figure 4 - Percentage changes of 2D surface roughness parameters between the symmetric, entry and exit side planes

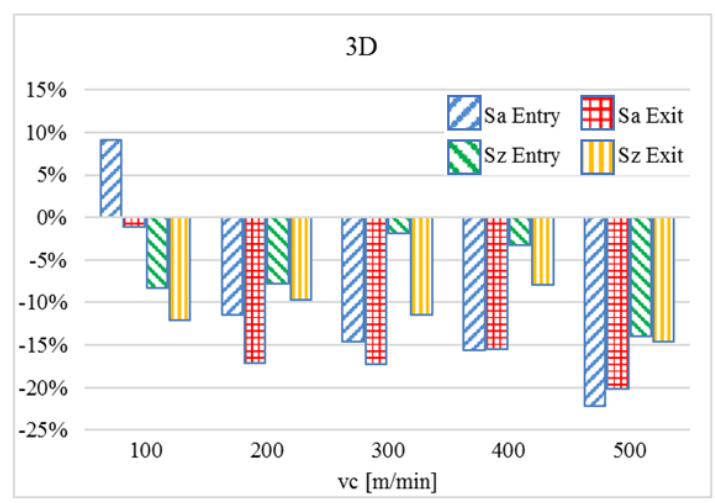

Figure 5 - Percentage changes of 3D surface roughness parameters between the symmetric, entry and exit side planes 


\section{CONCLUSIONS}

In the present work, face milling experiments with a single round insert were conducted on steel workpieces at various cutting speed values in order to determine the correlation of cutting speed and surface roughness. The variation of surface roughness with the cutting speed was investigated not only in a single area of the workpiece, but on three planes parallel to the feed direction. From the analysis of the results, several useful conclusions were drawn.

Surface roughness values were found to decrease considerably between cases of $100 \mathrm{~m} / \mathrm{min}$ and $200 \mathrm{~m} / \mathrm{min}$ cutting speed and then the variation of surface roughness was almost minimal. Thus, it becomes obvious that, from the studied cutting speed values, a $200 \mathrm{~m} / \mathrm{min}$ or more is recommended for obtaining good surface roughness. The highest decrease of surface roughness values was observed on the entry side plane and the highest values of surface roughness occur mostly on the symmetric plane. When surface roughness values between entry and exit side planes are compared, better surface quality is obtained in the exit side, where down-milling occurs, almost in every case. Finally, in the point of view of surface homogeneity, the cutting speed of 300 $\mathrm{m} / \mathrm{min}$ gave the best result.

\section{ACKNOWLEDGEMENTS}

The authors greatly appreciate the support of the National Research, Development and Innovation Office - NKFIH (No. of Agreement: K 116876).

The described study was carried out as part of the EFOP-3.6.1-16-00011 "Younger and Renewing University - Innovative Knowledge City institutional development of the University of Miskolc aiming at intelligent specialization" project implemented in the framework of the program Szechenyi 2020. Both grants are gratefully acknowledged.

References: 1. Alharthi, N.H., Bingol, S., Abbas, A.T., Ragab, A.E., El-Danaf, E.A., Alharbi, H.F.: Optimizing cutting conditions and prediction of surface roughness in face milling of AZ61 using regression analysis and artificial neural network, Advances in Materials Science and Engineering, 7560468. (2017). 2. Subramanian, A.V.M., Nachimuthu, M.D.G, Cinnasamy, V.: Assessment of cutting force and surface roughness in $\mathrm{LM} 6 / \mathrm{SiC}_{\mathrm{p}}$ using response surface methodology, Journal of Applied Research and Technology 15, pp. 283-296. (2017). 3. Ghoreishi, R., Roohi, A.H., Ghadikolaei, A.D.: Analysis of the influence of cutting parameters on surface roughness and cutting forces in high speed face milling of $\mathrm{Al} / \mathrm{SiC}$ MMC, Materials Research Express 5(8), 086521. (2018). 4. Pathak, B.N., Sahoo, K.L., Mishra, M.: Effect of Machining Parameters on Cutting forces and surface roughness in Al-(1-2) Fe-1V-1Si Alloys, Materials and Manufacturing Processes 28(4), pp. 463-469. (2013). 5. Hernandez-Gonzalez, L.W., Perez-Rodriguez, R., Quesada-Estrada, A.M., Dumitrescu, L.: Effects of cutting parameters on surface roughness and hardness in milling of AISI 304 steel, Dyna 85(205), pp. 57-63. (2018). 6. Felhö, C., Karpuschewski, B., Kundrák, J.: Surface roughness modelling in face milling, Procedia CIRP 31, pp. 136-141. (2015). 7. Baek, D.K., Ko, T.J., Kim, H.S.: Optimization of feedrate in a face milling operation using a surface roughness model, International Journal of Machine Tools and 
Manufacture 41(3), pp. 451-462. (2001). 8. Muñoz-Escalona, P., Maropoulos, P.G.: A geometrical model for surface roughness prediction when face milling Al 7075-T7351 with square insert tools, Journal of Manufacturing Systems 36, pp. 216-223. (2015). 9. Zhenyu, S., Luning, L., Zhanqiang, $L$.: Influence of dynamic effects on surface roughness for face milling process, International Journal of Advanced Manufacturing Technology 80 (9-12), pp. 1823-1831. (2015). 10. Wang,R., Wang, B., Barber, G.C., Gu, J., Schall, J.D.: Models for prediction of surface roughness in a face milling process using triangular inserts, Lubricants 7(1), 9. (2019). 11. Pimenov, D.Yu., Bustillo, A., Mikolajczyk, T.: Artificial intelligence for automatic prediction of required surface roughness by monitoring wear on face mill teeth, Journal of Intelligent Manufacturing 29(5), pp. 1045-1061. (2018). 12. Bagci, E., Aykut, S.: Influence of symmetric and asymmetric machining strategies on surface roughness in face milling process of cobalt-based superalloy, Jounral of the Balkan Tribological Association 19(1), pp. 23-26. (2013). 13. Cui, X., Zhao, J.: Cutting performance of coated carbide tools in high-speed face milling of AISI H13 hardened steel, International Journal of Advanced Manufacturing Technology 71 (9-12), pp. 1811-1824. (2014). 14. Varga, G., Kundrák, $J .:$ Effect of technological parameters on surface characteristics in face milling, Solid State Phenomena 261, pp. 285-292. (2017). 15. European Steel and Alloy Grades/Numbers, C45, http://www.steelnumber.com/en/steel composition eu.php?name id=15/

Янош Кундрак, Антал Надь, Мішкольц, Угорщина, Ніколаос Е. Каркалос, Ангелос П. Маркопулос, Афіни, Греція

\title{
ДОСЛІДЖЕННЯ ШОРСТКОСТІ ПОВЕРХНІ ПІСЛЯ ТОРЦЕВОГО ФРЕЗЕРУВАННЯ КРУГЛОЮ РІЖУЧОЮ ПЛАСТИНОЮ В ПЛОЩИНАХ, ПАРАЛЕЛЬНИХ НАПРЯМКУ ПОДАЧІ
}

\begin{abstract}
Анотація. У иій статті розглядається шорсткість поверхні, одержуваної шляхом симетричного торцевого фрезерування. В ході дослідницьких робіт вивчався вплив використання круглої фрезерної пластини на топографію поверхні при різних швидкостях різання. 2D i 3D вимірювання шорсткості поверхні проводилися в трьох площинах виміру, паралельних напрямку подачі, причому одна з них представляла собою площину симетрії, а дві інші - на однаковій відстані від неї, з обох сторін. В даній роботі експерименти по фрезеруванню з однією круглою пластиною проводилися на сталевих заготовках при різних значеннях швидкості різання, щчоб визначити кореляцію швидкості різання $і$ шорсткості поверхні. Як правило, можна констатувати, ще значення шорсткості, отримані на поверхні, щцо створюється вставкою круглої форми, спочатку раптово зменшуються, а потім залишаються практично незмінними з збільшенням швидкості різання. 3 аналізу результатів були зроблені кілька висновків. Було виявлено, щя значення шорсткості поверхні значно зменшуються між випадками швидкості різання 100 м / хв і 200 м / хв, $i$ потім зміна шорсткості поверхні було майже мінімальним. Таким чином, стає очевидним, що з вивчених значень швидкості різання рекомендується 200 м/хв або більше для отримання хорошої шорсткості поверхні. Найбільше зменшення значень шорсткості поверхні спостерігалося на площині вхідної сторони, а найбільші значення шорсткості поверхні спостерігаються в основному на симетричній площині. Коли порівнюються значення шорсткості поверхні між площинами боку входу і виходу, кращу якість поверхні досягається на стороні виходу, де відбувається фрезерування, майже в кожному випадку. Нарешті, з точки зору однорідності поверхні швидкість різання 300 м / хв дала найкращий результат. Крім того, більш високі значення шорсткості поверхні спостерігаються в симетричній площині, ніж в інших паралельних площчинах.
\end{abstract}

Ключові слова: ториеве фрезерування; симетричне фрезерування; кругла пластина; шорсткість поверхні. 